
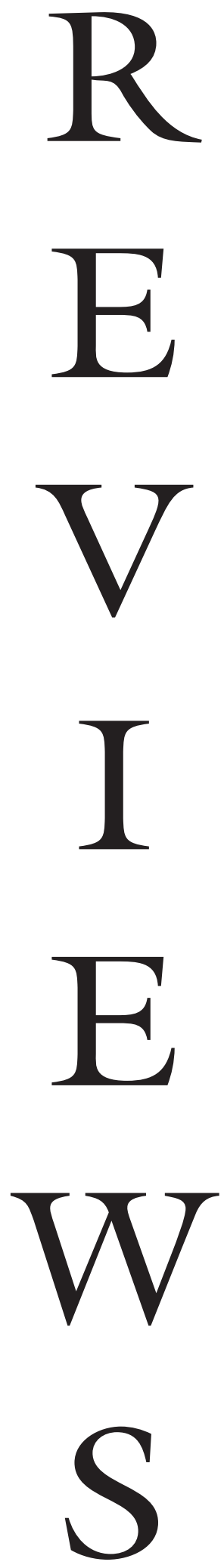

STRANGE BEDFELLOWS THEN AND

NOW -

WHITE SLAVES AND TRAFFICKING

Jo Doezema: Sex Slaves and

Discourse Masters - The Con-

struction of Trafficking.

Zed Books. London \& New

York. 2010. 216 pages. \$27.

$\mathrm{O}$ ver the past decade, mounting public attention has been directed toward the 'traffic in women' as a dangerous manifestation of global gender inequalities. An attention which has spurred an outcry for rescuing the trafficked women and imprisoning the traffickers. This attention is not only public, but also indeed academic and Jo Doezema has contributed significantly to the academic trafficking discourse over the past 15 years. Doezema's critical perspectives on existing trafficking discourses group her among other trafficking scholars such as Laura Agustin, Julia O'Connell Davidson, Bridget Andersson, Kamala Kempadoo, Denise Brennan and Elizabeth Bernstein among others, who from a range of angles have questioned simple dichotomies of victims and perpetrators, as well as emphasizing the agency of sex workers. In Sex Slaves and Discourse Masters - The Construction of Trafficking Doezema combines contemporary investigation with historical analysis of trafficking discourses. The main questions asked are why there has been such a mounting attention toward trafficking? Why does the story of trafficking sound so familiar? How does the discourse resonate with debates during the white slave trade?

\section{The Problem With}

\section{Consent}

The book's point of departure is that trafficking is not a discursively neutral terrain. The conflicting problems within NGOs, governments and academia regarding the prevalence and severity of trafficking are connected to problems with a definition of what trafficking really means. This continuous problem with definition has not, however, lead to the degree of caution in regard to policy that could be expected - which results in trafficking po-licies sometimes doing more harm than good to the women they were aimed at helping. Yet, according to Doezema the answer to the lack of hard trafficking data and definition should not necessarily be more research, but rather an investigation into the politics of numbers, the myth and narratives, which exist within the field of trafficking. This is a gap Doezema compellingly fills out, as she argues that the problems with defining what trafficking might mean tells a story in itself.

Doezema reintroduces three analytical concepts: 'myth', 'ideology' and 'consent', and uses these concepts to interrogate the truth claims - both empirical and theoretical about trafficking in women through a genealogical examination of the historical circumstances of their production. In this way the book serves as a 
historically founded discourse analysis of the epistemology of trafficking - a perspective which in essence is concerned with the relationship between power and knowledge. How do we know what we know about trafficking? And why do we believe in it?

One central answer being that the problem of definition emerges because the entire discourse on prostitution and trafficking rely on the consent standard. That is, conflicting and moralistic determined views on the ways in which consent plays a part in prostitution and trafficking. In this way Doezema's arguments revolve around a question still often unresolved by feminists in academia; what are the ways in which women might consent to gendered practices commonly understood as exploitative?

\section{STRANGE BEDFELLOWS - THEN AND NOW}

Doezema in her own words unearthes the trafficked woman through exhuming the buried images of 'the white slave'. The image of the white slave was that of white women being kidnapped, trapped and sexually abused by the racial other - 'the black man'. Examining the archives of the white slave trade and the forming of UN anti-trafficking protocols she argues that the contemporary figure of the trafficking victim can be analyzed as a construction - a construction very similar to 'the white slave' 150 years ago. That is, both figures work metaphorically, but are much more complex figures empirically.

The question then is why did and does the figure of the female slave work as such a strong metaphor? Doezama argues that the debates concerning the figure of the white slave served as a melodrama, which celebrated the firm boundaries of home and family - as a place were women belonged. The narrations and portrayals of the white slave trade displayed the fears, sexual dangers and imaginations of purity and social order, which circulated in that particular context. This melodrama seemed to incorporate multiple categories and identities which were compelling, as also prostitution historian Judith Walkowitz has argued, to a variety of social constituencies. Constituencies, which historically and in present time are rarely combined in other realms but trafficking. Yet, contemporary trafficking arenas and the white slave campaigns engaged and engage socialists, republicans, feminists, protestant reverends and a range of other religious movements - creating a curios group of strange bedfellows. Despite the good intentions of the campaigns, however, the engaged participants often seemed and seem far removed from their objects of compassion producing a hierarchical and objectifying relation to the women they wanted and want to rescue.

Then as now there is something compelling, almost 'sexy' in wanting to save sex slaves. Whereas fighting for migrants rights and questioning global inequalities as the root causes to trafficking seems dull, boring and 'unsexy.' The figure of a non-chained woman who sells sex because she finds she has no other options at a particular time of her life does not serve as a powerful image strong enough to form a movement. That is, the woman who under specific circumstances has consented to sell sex was not, and is not, of particular interest to those who want to rescue sex slaves. Violence, sex, slaves and perpetrators were and are apparently needed to create melodramatic stories and political engagement. Along these lines Doezema concludes that a focus on sex slaves is not necessarily based on empirical realities, but rather because the figure can be perceived to be true at a certain moment. Or perhaps put more simply, because the figure of the slave works politically at certain moments. In this vein the book compellingly illuminates the clash between the good intentions, humanitarianism and the lived realities of the women they tried and try to save.

\section{Same Figure - Same Fears?}

Thus, there are indeed close similarities with the figure of the white slave and contemporary times portrayals and images of the trafficked woman. This perspective cements the book as crucial reading for everyone interested in feminism, prostitution and trafficking, but even more so for those interested in epistemology and the relationship be- 
tween power and knowledge.

Yet, one question to ask the book is: can we fruitfully compare early white slave discourses to new discourses on trafficking? Back then the discourse on the white slave was concerned with family and bourgeois ideologies. But is this the same now? The comparison seems valid following the argument that prostitution becomes significant at particular historical moments where women, sexuality and exchange become crucial. The comparison also seems valid as Doezema argues that moral views on sexuality and prostitution play a huge part in contemporary discourses on trafficking as it did then. Still, are contemporary anxieties over the 'women as slave' the same as then?

Following the logic of Ann Laura Stoler's point; 'where boundaries are fragile panic erupts', we also now witness the moral panic in the wake of trafficking, as during the white slave trade. Yet, it still seems that the anxieties are different. The boundaries appear fragile for other reasons than during the white slave trade. First, it seems that at this moment ideas of masculinity are being transformed and sought cultivated - mirrored in the increasing focus and pathologizing of the male buyer of sex the customer. Secondly, the role and anxieties of the nation state are different in a globalised world than in Victorian times with increasing attention to protect borders against undocumented immigration, smuggling and trafficking.
Finally, one could argue that the focus on criminal justice in relation to trafficking works stronger because social justice and redistribution seem so elusive at this moment.

Doezema writes thoroughly, vividly and smart and Sex Slaves and Discourse Masters The Construction of Trafficking compellingly deconstructs the constructions of the sex slave figure. This project of deconstructing the concept of trafficking has been an ongoing fruitful and crucial endeavour among trafficking scholars the past 10 years. Yet, what should come next then is hopefully a reconstruction of the deconstructed. In this way, Doezema's final remarks are a bit disappointing, as she admits to not being really able to move beyond consent as the yardstick by which prostitution and trafficking are measured. As a feminist she finds her own perceptions of sexuality deeply entwined with notions of consent. As a sex worker activist she is deeply invested in 'sex worker rights', ideas that are similarly tied to consent. As long as we cannot find another concept but consent to measure prostitution and trafficking by, we fail to move beyond the constructions of trafficking and the spectre of the white slave cannot be laid to rest.

Sine Plambech, PhD-Candidate in Social Anthropology at The Danish Institute for International Studies, Unit of Migration. Currently Research Scholar at Columbia University, New York.
PROMISING PROJECT, LIMITED RESULTS

Naila Kabeer et al (eds.): Global Perspectives on Gender Equality. Reversing the Gaze. Routledge. 2008. 294 pages. $£ 23.70$.

$\mathrm{T}$ he book project Reversing the Gaze was initiated in 2004 by the Swedish Expert Group on Development Issues (EGDI), established by the then social democratic government. The EGDI ceased to exist May 2007, as a part of the cuts and re-directions of Swedish development aid, which followed as a consequence of the liberal take-over of the Swedish government after elections 2006.

From 2004 onwards, according to one of the editors, "the project attracted an extraordinary amount of interest, compared to the numerous other research projects in which I have participated". Everybody wanted to give advice and/or had expectations to the outcome of the research. I myself belonged in the latter category; working in Sweden 2000-2007 I also knew of the research project, which I found very innovative and interesting. The general pattern being Northern scholars and consultants investigating the global South with points of departure in ideas and models rooted in Europe/ the West, it felt very relevant and needed to 'reverse the gaze' and look at the global North - in this case the Nordic countries from scholarly positions in the South. Based on my knowledge of postcolonial feminist 
scholarship I expected a thorough questioning of Western notions of women and gender, and discussions of the very idea of gender equality.

The result of the project, published as a book by Routledge 2008 (hardcover at a forbidding price, since 2009 , however, also available in paperback) does not fulfill those expectations. The book is not a work of postcolonial scholarship. It does not, like e.g. the work of Oyèrónké Oyewùmí, investigate the epistemological roots of Western gender discourses (Oyewùmí 1997, 2002) nor does it, like e.g. the work of Dipesh Chakrabarty, battle with the simultaneous indispensability and inadequacy of European thought (Chakrabarty 2000).

The general framing of gender equality discourse in the Nordic countries is not questioned; the book moves within the conceptual universe of Western (now global) feminism, defining its project as comparative, "comparing Nordic and developing country approaches to gender equality". Nine of the articles of which the book is composed consist of comparative investigations of selective aspects of gender equality policies, between Sweden and/or Norway on one hand, and the author's country of origin (Pakistan, India, South Africa, Mexico, Hungary being among them) on the other, while the introduction and two concluding chapters written by the editors discuss crosscutting issues.

The scope of the book thus being more limited in theoreti- cal terms from what initially I had imagined, it does, however, provide some interesting food for thought regarding different understandings of gender equality. The gaze from unexpected inroads does give some new insights and issues on which to reflect regarding different approaches to political projects of gender equality in Sweden and Norway respectively.

\section{'Difference' vs 'EQUALity' APPROACHES TO POLITICS OF GENDER}

Discussions of 'difference' vs 'equality' feminism have taken place in all of the Nordic countries, 'difference' feminism, however, generally being discredited as rooted in maternalist politics and essentialist notions of women. What emerges from this study is that feminist struggles, particularly in the 1920s and 1930s, were driven by a discourse of 'difference' with attention to the specific qualities and contributions of women, while a discourse of 'equality' stressed women's identity as workers side by side with men. A crucial period was in the mid 1930s when a debate of married women's right (or not) to salaried work was turned into an issue of working women's right to marry and have children. Alva Myrdal, prominent Swedish social democrat and feminist of the time, was responsible for this discursive turn, which laid the ground for Swedish gender equality policies in years to come. Family law is couched in gender neutral language, invisibilizing aspects of women's lives and bodies (such as giving birth and breastfeeding babies) which cannot be talked about in gender-neutral terms. On the other hand, women's organizations focused on women's interests as women, with points of departure in motherhood and domesticity and the need to give equal value to women's unpaid domestic labour. Norwegian feminists thus started out with a politics of difference to argue for equal rewards for paid and unpaid work, while Swedish feminists organized around a politics of equality that sought to equalize the gender division of labour at work and in the home.

Differences between Norwegian and Swedish approaches are less outspoken today, the 'equality' approach having taken over - an approach which also matches the global politics of Gender and Development as spearheaded by the World Bank and (to a certain extend) based on the outcomes of the 1995 Beijing Fourth UN World Conference on Women. Nevertheless, according to Naila Kabeer, the Norwegian experience, with its history of the resourceful reimagining of the meaning of motherhood, appears to have a more immediate relevance for feminist struggles in societies of the global South. In addition to Naila Kabeer's concluding article, also the articles on Sweden/Argentina (by Elizabeth Jelin) and on Norway/ Iran (by Shahra Razavi) elaborate on the difference/equality dilemmas. Is the gender neu- 
trality approach the appropriate route for gender equality? How can we combine the logic of equality with a logic of differences? According to Elizabeth Jelin the tension between gender equality and the recognition of difference can only be approached through the recognition of women's and men's embeddedness in systems of social relations, and less so in individualistic frameworks. Thus, in addition to the difference/equality dilemma she also suggests an individualisation/community dilemma: the tensions between individualisation and a sense of community, as that between equality and difference, are some of the dilemmas we still face.

\section{THE EPISTEMOLOGICAL BLIND SPOT IN NORDIC FEMINISM}

Some of the chapters in the book point to the fact that with increasing diversity in the Nordic countries, populations being composed of people from many corners of the world, 'gender equality' tends to become a marker in delineating boundaries between Nordic and 'other' cultures. Gender equality is something 'we' have got, but 'they' are lacking. Immigrant men are seen as more patriarchal than Nordic men, immigrant women thus more oppressed than Nordic women. When immigrant men batter their women it is interpreted as a part of their 'culture' while issues of Nordic men battering their women are seen as individual dysfunctions. Intersectional analysis of crosscutting power hierarchies of gender, class and race is very popular in theoretical contexts in Nordic feminist thinking, but when it comes to practical politics and media debates, intersectionality tends to be replaced by racism and 'othering', immigrant women being conceived as hapless victims of male power and dominance. This 'epistemological blindness' has only sporadically been dealt with in feminist analysis of the Nordic countries, one recent contribution, however, being the 2009 volume Complying with Colonialism: Gender, Race and Ethnicity in the Nordic Region, edited by Suvi Keskinen et al.

Signe Arnfred, Associate Professor, Institute for Society and Globalization, and Centre for Gender, Power and Diversity, Roskilde University.

\section{LITERATURE}

- Chakrabarty, D. (2000):

Provincializing Europe, Princeton University Press.

- Keskinen, S et al (eds.) (2009): Complying with Colonialism: Gender, Race and Ethnicity in the Nordic Region, Ashgate, Surrey. - Oyewùmí, O. (1997): The Invention of Women. Making an African Sense of Western Gender Discourses, University of Minnesota Press, Minneapolis, London. - Oyewùmí, O. (2002): Conceptualizing Gender: The Eurocentric Foundations of Feminist Concept and the Challenge of African Epistemologies, in JENDA: A Journal of Culture and African Women's Studies, 2,1, 2002.

\section{REVISITING THE} 'MAN' QUESTION

Jane Parpart and Marysia Zalewski (eds.): Rethinking the Man Question. Sex, Gender and Violence in International Relations. Zed Books, 2008, 226 pages. Price: £16,14.

Tn 1998 Zalewski and Par1 part first posed the 'Man' question in international relations studies with a ground breaking volume of articles showing that 'gender is an integral, not an accidental feature of the worldwide structures of diplomatic, military and economic relations' (Foreword by Connell viii). 20 years later the two editors revisit the field of international relations in order to 'produce responsible and politically effective knowledge about gender and sex through an academic discipline traditionally marked by rigorous, even violent, methodological policing of its epistemological and ontological borders' (Parpart \& Zalewski 2008: 1). With a Preface by Raewyn Connell and Afterword by Cynthia Enloe, the volume is from the outset endowed with high praise from the very core of feminist studies of international politics.

The collection of articles offers fresh readings of the key issues, which the 1998 publication brought to light, placing these issues in contemporary political concerns associated with the post $9 / 11$ world order. The concerns associated with terror, security and protection are skillfully read through the lens of gender, drawing important new inspi- 
ration from the fields of queer and postcolonial theory.

In the opening article Kimberly Hutchings argues that masculinity effectively limits theoretical innovation in the field of international politics because it functions as ' $\mathrm{a} \operatorname{cog}$ nitive short cut', as 'the logic of masculinity provides a powerful incentive against raising questions about the substantive assumptions and inductive and deductive moves' in analyses of international politics.

Kevin Dunn takes issue with the academic disciplines and institutions of international politics, arguing that 'white male privilege' via of gate keeping and institutionalized white + male centrism creates not only blind spots in terms of theory creation, but constitutes a self asserting logic which shapes and orders the field to benefit white males, and subsequently exclude nonwhite, non-male points of view and indeed also individuals.

Revisiting a dominant theme from the 1998 'Man Question', Terrell Carver, Cristina Masters Sandra Whitworth, Daniel Conway, Jamie Munn, Dibyes Anand and Jane Parpart all interrogate the interconnection between militant masculinity and ideas and images of state- and nationhood. Carver investigates Western forms of masculinity; the warrior-protector and the rationalbureaucratic masculinities as bound up on mechanistic metaphors, derived from Hobbes, and laying the ground for the gendered division between civilization/barbarism and vulnerability/in-vulnerability. $\mathrm{He}$ argues that this division, is not only practically in-manageable, it's mythical framework produces particular groups of people as needing protection/ others who do not, thus dichotomizing the human experience. In the same vein, Cristina Masters argues that the intersection between technoscience and masculinist power discourses produces the biopolitical architecture for the construction of 'US cyborg soldiers'. Sandra Whitworth argues that the efforts to main militarized hegemonic notions of masculinity in the face of post-traumatic stress disorder, consists of a constant denial of feelings of fear, terror and emotional pain in the idealized notions of 'the soldier'.

Where Carver, Masters and Whitworth interrogated Western contexts, Conway, Munn, Anand and Parpart analyze the relation between masculinity state- and nationhood in nonwestern contexts with reference to tendencies in international relations scholarship to view these relations via a Eurocentric notion of masculinity. Daniel Conway examines the intersection between notions of whiteness and masculinity in Apartheid South Africa as intricately connected with a gendered hierarchy where feminine, queer and racialized others functioned as the constitutive others. This, Conway argues, opened up possibilities for dissident masculinities to undercut the masculinist order of the state. Jamie Munn studies the complex relationship between nationalism and masculinity in post-conflict Koso- vo. Munn argues via Butler that non-hegemonic masculinities, such as the performance of homosexuality, may destabilize the interconnection between nationalism and masculinity. With point of departure in Enloe, Dibyesh Anand analyzes Hindu nationalism, arguing that idealizing specific notions of Hindu heterosexual masculinity and vilifying Muslim notions of masculinity as hyper-sexualized functions as a narcissistic projection of anxiety and desire. Jane Parpart's cross reading of Rhodesian and Zimbabwean militarized masculinities poses the argument that these opposed nationalisms drew symbolic meaning from a similar set of masculine ideals and practices of violence both during the liberation war, and in post-colonial nation building; laying the ground for an authoritarian militarized masculinity which underpinned and legitimized control over the post-colonial state.

The book offers compelling readings of the power dynamics of images and norms of masculinity in nationalism and inter-national relations. The individual articles each contribute to the growing literature which seeks to 'gender' seemingly neutral fields within social science, and reiterate the continued need for careful analyses, which de-constructs the naturalized 'rational man' in the social sciences.

Lene Bull Christiansen, Acting Assistant Professor Cultural Encounters Roskilde University. 